\title{
EVALUATION OF LARGE-SCALE LOAD-CARRYING STRUCTURES OF MACHINES WITH THE APPLICATION OF THE DYNAMIC EFFECTS FACTOR
}

\section{OCENA WIELKOGABARYTOWYCH USTROJÓW NOŚNYCH MASZYN Z ZASTOSOWANIEM WSPÓŁCZYNNIKA OBCIĄŻEŃ ZASTĘPCZYCH*}

\begin{abstract}
Load-carrying structures of large-scale machines are their key element, mainly due to their size which renders them virtually impossible to replace during operation. Such structures are used for example in the heavy industry, mining, bulk material handling or rock processing. This article presents the most important results of recent research into dynamic loads and design of such structures. Based on these results the article introduces the author's method of evaluating load-carrying structures with the application of the dynamic effects factor and describes the effects of the application of this method.
\end{abstract}

Keywords: load-carrying structures, numerical simulations, experimental testing, design, dynamic loads.

\begin{abstract}
Ustroje nośne maszyn wielkogabarytowych sa ich kluczowym elementem, ze względu na ich rozmiar a tym samym niemalże brak możliwości wymiany $w$ trakcie eksploatacji. Ustroje tego typu stosowane sa $n p$. w przemyśle wydobywczym, przetadunkowym czy przetwórstwa skalnego. W artykule zebrano i zaprezentowano wyniki najważniejszych badan ostatnich lat dotyczacych obciażeń dynamicznych oraz projektowania tego rodzaju obiektów. Na tej podstawie przedstawiono autorska metodę oceny ustrojów nośnych z zastosowaniem wspótczynnika obciązeń zastępczych oraz efekty jej stosowania.
\end{abstract}

Stowa kluczowe: ustroje nośne, obliczenia numeryczne, badania eksperymentalne, projektowanie obciażenia dynamiczne.

\section{Introduction}

Because of the enormous size of the undertaking, large-scale load-carrying structures of machines, are designed with long-term operation in mind [36]. Therefore they must satisfy both the ultimate strength requirement as well as the fatigue strength requirement. This is particularly important in the case of mechanical structures, which are likely to undergo variable cyclic loading which, in many cases, directly result from the dynamics of structure [32]. This is the basic difference compared to large-scale load-carrying structures

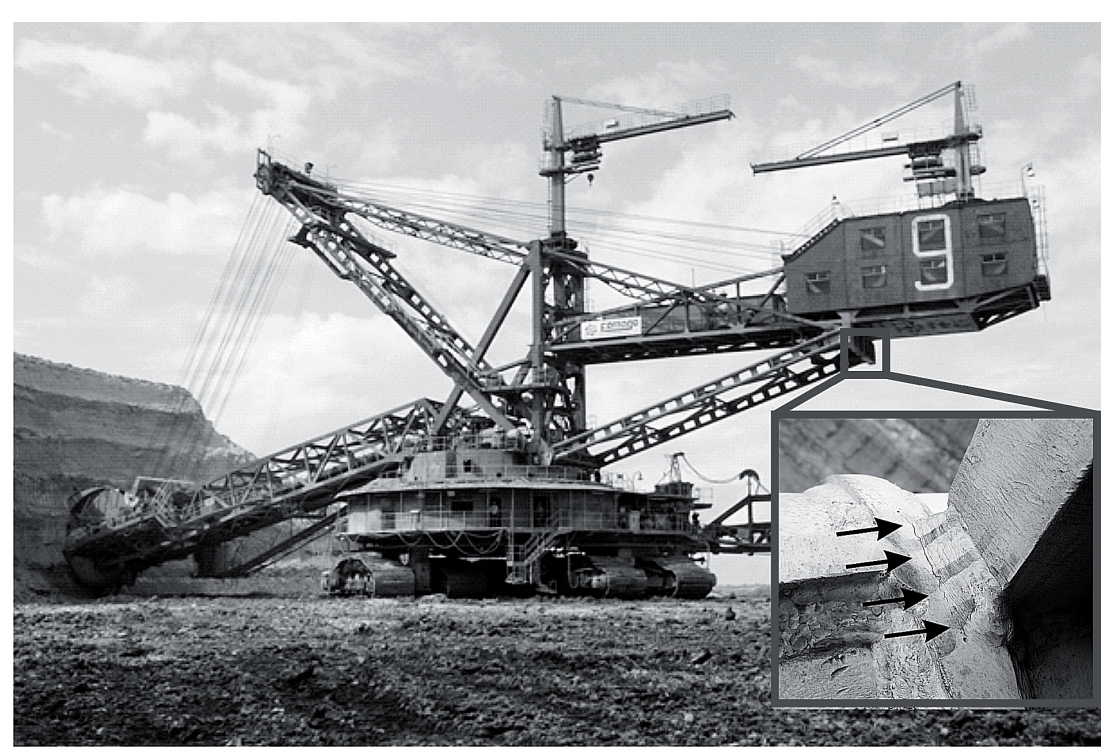

Fig. 1. Developing fracture crack in the construction industry which are usually designed to transfer only static loads and thus only need to fulfill the ultimate strength requirement. Dynamic loads accelerate the progressing degradation of the load-carrying structure, which is manifested in an increasing number of fatigue cracks. Fig 1 shows an example of a fracture and its location.

Such faults are difficult to spot and if the fracture is located in a critical area, it can grow uncontrollably and lead to a catastrophic failure. A fracture similar to the one in Fig. 1 caused the catastrophe of the KWK 1400 excavator (Fig. 2).

Such load-carrying structures are most often found in the mining, rock processing or bulk material handling industry. The situation in this case is even more special because some of the basic technological processes (e.g. excavating, crushing) are very often subject to large dynamic loads $[15,16]$. Due to the environment in which such machines most often operate, it is difficult to use solutions that are effective at reducing vibrations but are not susceptible to damage $[2,48]$. In addition, the design of load-carrying structure can be prone to excitation $[7,17]$ (e.g. long-span superstructures of surface mining machines).

Such machines are still being designed in accordance with standards from the 1980 s, which define the dynamic effects factor, which, in turn, is used in calculations of fatigue life. Both the definition of this factor and its assumed values, in accordance with the standards, do not reflect the actual operating conditions. This is manifested in the occurrence of numerous cracks in superstructures $[1,12,37]$ and undercarriage structures $[1,4,13,46]$. Over the years several studies have been carried out aimed at solving this problem

$\left(^{*}\right)$ Tekst artykułu w polskiej wersji językowej dostępny w elektronicznym wydaniu kwartalnika na stronie www.ein.org.pl 


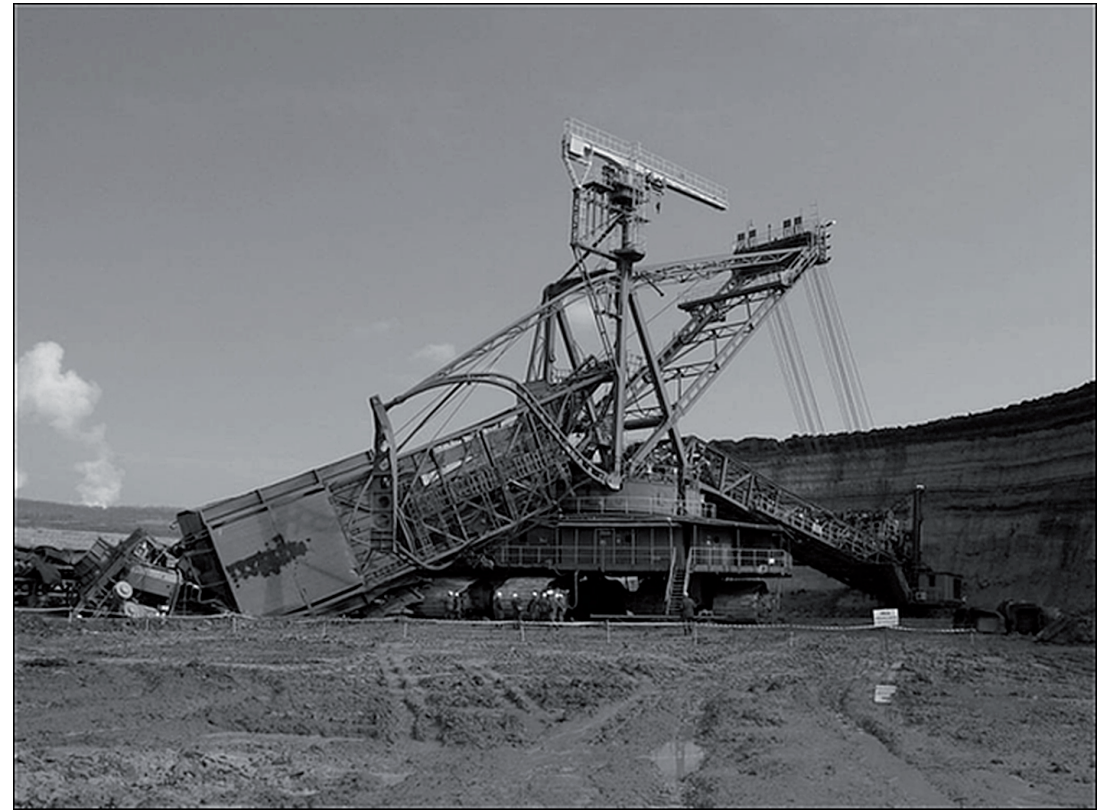

Fig. 2. Catastrophic results of fracture crack [37] are defined exactly as in the DIN standard, i.e. by applying the factor. However, as stated in the AS standard, the values of dynamic effects factors in the DIN standard do not correspond to the values of actual dynamic loads. Therefore, the values of this factor in the AS standard are higher in most cases. What the Australian norm also states is that, as a result, machines designed on the basis of the AS standard will be heavier than those designed on the basis of the DIN standard. Whenever calculations are based on the ISO standard, solutions based on the DIN standard are often used in order to account for the dynamic effects.

To calculate dynamic effects [18] when designing large-scale machines, the German approach defines the dynamic effects factor $\psi$. Based on the appendix to the standard it can be concluded that the physical interpretation of this factor means the ratio between the measured peak-to-peak acceleration value and the constant value of gravitational acceleration (1):

$$
\psi=\frac{\Delta a}{g}
$$

[29]. In his work [24], Kowalczyk proposes to control the assumed values by changing the settings of the protection systems in the machine. The change is carried out in real time during operation. This solution requires that a monitoring system be installed on the machine and connected to its control system. It also restricts the use of the said dynamic effects factor on a standard basis only to cases where the calculated range of stress changes is smaller than the range resulting from the applied static load. On the other hand, in another paper [20], Huss shows the use of dynamic load surpluses in relation to overloads. This paper focuses on identifying impacts and introducing a measure of their effects on the load-carrying structure. In their article, Bosnjak et al. [5] address the influence of rigidity of individual assemblies of the load-carrying structure on the dynamic response of the system. Their analysis is carried out on a flat model with four degrees of freedom. In his doctoral thesis [19], Gnjatovic presents his own reduced, three-dimensional dynamic model. He uses it to measure the response of the system to the loads defined in the DIN standard.

However, the presented approaches require the designer to have comprehensive knowledge and do not correspond to design methods commonly used in the industry. As a result they are either only used occasionally (Kowalczyk [24]) or have never been implemented. Consequently, the machines that have been designed since, are mainly based on outdated literature and standards. Currently, the most commonly used guidelines are international standards:

- German Institute for Standardization (2015) - DIN 22261-2 [18]

- Standards Australia (1995) - AS 4324.1 [47]

- International Organization for Standardization (1994) - ISO 5049.1. [22]

The German standard is the most common point of reference when designing load-carrying structures of large-scale machines. The Polish calculation standard for surface mining machines is a translation of the German standard. This standard was the first to introduce calculations with the application of the dynamic effects factor. The ISO standard, on the other hand, does not provide any specific calculation procedure which would require the use of dynamic loads. It states that the drives and brakes should be designed in such a manner that the acceleration of machine components does not exceed $0,2 \mathrm{~m} / \mathrm{s}^{2}$ $(\sim 1 / 50 \mathrm{~g})$. The Australian standard is based largely on the abovementioned DIN and ISO standards. In general, the problems of dynamics
$\Delta a=\max a-\min a$

where

$a$ - measured value of acceleration

$\mathrm{g}$ - value of gravitational acceleration.

This definition raises some doubts due to the high sensitivity to individual events, which may influence the measured value. The application of the $\psi$ factor, defined in this particular manner, would only be justified if the analyzed dynamic process was stationary, which is very difficult to achieve under operational conditions $[21,36]$.

The values of the factor defined in the DIN standard are presented in Table 1.

It should be pointed out that the information presented above comprehensively covers the issues of dynamics described in the standards. The defined factors are substitute values for the dynamic load and are used in static calculations. Their application only allows for the estimation of the stress of the structure that can cause particular dynamic overloads. Of crucial importance is the application of these factors in fatigue calculations. As many as 3 of 8 components in fatigue load cases are dynamic loads. Unfortunately, the replacement of dynamics with a dynamic effects factor completely overlooks the essence of dynamics in the studied structures. In accordance with the recommendations, or rather due to the absence thereof, no analysis is performed of the structure's dynamic response, nor of the possible resonant excitation e.g. by the overlapping of excitation derived from excavation frequency with mode shapes. Based on both the DIN and ISO standards, the Australian standard introduces new recommendations related to the analysis of possible resonant excitations generated by the digging frequency of buckets. The modernization of existing load-carrying structures in accordance with this recommendation is presented in the research paper [33].

It is also not mandatory to carry out verification by experimental tests. Therefore, there is no method of measurement which would clearly define the procedure for measuring and verifying the assumed dynamic loads. The appendix to the DIN standard does offer sample measurements but there are no recommendations for their implementation, which, in the case of such phenomena, can have a huge impact on the results. As shown in Fig. 3, the grid of measurement points does not cover the entire machine and there is no justification as to why these particular points were selected. Particular attention should 
Table 1. Values of $\psi$ coefficient in accordance with DIN standard[18]

\begin{tabular}{|c|c|c|c|c|}
\hline \multirow{2}{*}{ Machine type } & \multirow{2}{*}{ Machine element } & \multicolumn{3}{|c|}{ Dynamic effects factors $\psi$} \\
\hline & & Vertical $D_{V}$ & Transverse $\mathrm{D}_{\mathrm{Q}}$ & Longitudinal $\mathrm{D}_{\mathrm{L}}$ \\
\hline \multirow{2}{*}{$\begin{array}{l}\text { Bucket wheel } \\
\text { excavator }\end{array}$} & Bucket wheel boom & $1 / 10$ & $1 / 60$ & 0 \\
\hline & $\begin{array}{l}\text { Tower or central structure with counter- } \\
\text { weight boom }\end{array}$ & $1 / 25$ & $1 / 30$ & 0 \\
\hline \multirow{4}{*}{$\begin{array}{l}\text { Bucket-chain } \\
\text { excavator }\end{array}$} & Bucket chain boom with cable supports & $1 / 7$ & $1 / 30$ & 0 \\
\hline & $\begin{array}{l}\text { Main support frame in the hoisting area } \\
\text { of the chain boom }\end{array}$ & $1 / 10$ & $1 / 30$ & 0 \\
\hline & Central structure & $1 / 30$ & 0 & 0 \\
\hline & Counterweight boom & $1 / 20$ & $1 / 50$ & 0 \\
\hline \multirow{3}{*}{$\begin{array}{l}\text { Crawler mounted } \\
\text { spreader }\end{array}$} & Discharge boom & $1 / 10$ & $1 / 10$ & 0 \\
\hline & Tower - central part & 0 & 0 & 0 \\
\hline & Counterweight boom & $1 / 20$ & $1 / 15$ & 0 \\
\hline \multirow{2}{*}{$\begin{array}{l}\text { Crawler mount- } \\
\text { ed machines }\end{array}$} & Connecting bridges & $1 / 20$ & $1 / 10$ & $1 / 15$ \\
\hline & Cabs for operators & $1 / 2$ & $1 / 2$ & $1 / 2$ \\
\hline
\end{tabular}

be paid to the points that measure acceleration and are located on the undercarriage. Given the nature of vibrations in the presented structures $[11,28,30]$, it can be assumed that the values measured in these points will not be large. Presumably, this is why these values were not included or discussed in the standard. However, it is erroneous to assume that dynamic loads will not act on the undercarriage components.

Dynamic load factors have been used for a long time in the design of cranes [26, 27], with the difference that they apply to the dynamic forces originating from the lifted mass and their value depends on the lifting velocity. Mass forces are determined on the basis of accelerations (dynamic effects) that depend on the characteristics of the drives, which follows the recommendations of the ISO standards.

Based on the above information it can be concluded that the commonly accepted method of designing large-scale machines based on the dynamic effects factor essentially ignores the dynamics of the structures that are being designed. Additionally, even static calculations based on the dynamic effects factor fail to take into account the dynamic effects that machine superstructures have on elements of the undercarriage. Furthermore, there is no well-defined method of experimental tests which could be used to verify the actual values of the assumed factors so as to obtain an approximation of the conditions and time of safe operation.

\section{Research on the dy- namic effects factor}

The aforementioned gaps in knowledge on the dynamics of structures of large-scale machines have become the basis for numerical and experimental studies in recent years. The second chapter presents the author's original studies and their results. These studies were focused on the possibility to develop solutions that could be applied easily to current design guidelines and at the same time could solve the discussed problems related to dynamics of machines.
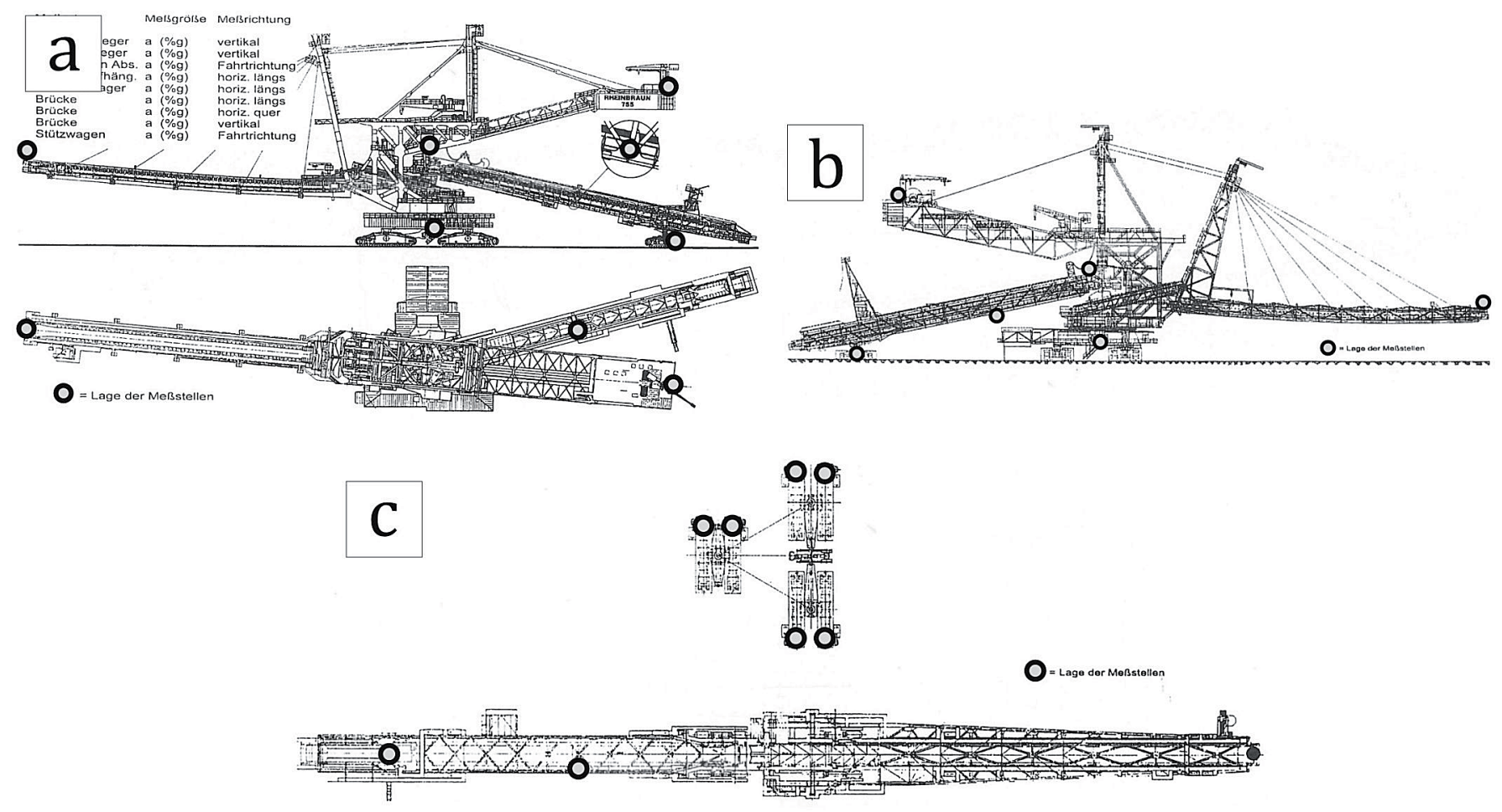

Fig. 3. Distribution of measuring points according to DIN [18] 


\subsection{Experimental studies of the actual values of the dynamic effects factor}

Long-term operation of steel load-carrying structures of largescale machines has led, in recent years, to the need to assess the technical condition of these structures. This is caused by their decreasing life expectancy. In the absence of recommendations and procedures for such tests, it was necessary to develop a method that could help assess their technical condition. Such an assessment is very complex $[8-10,35,38]$ and incorporates verification by numerical calculations of the machine, experimental determination of actual load values, defectoscopic tests, analysis of previous modernizations, repairs and events that could have permanently affected the load carrying capacity of the structure. The conducted $\mathrm{a}$

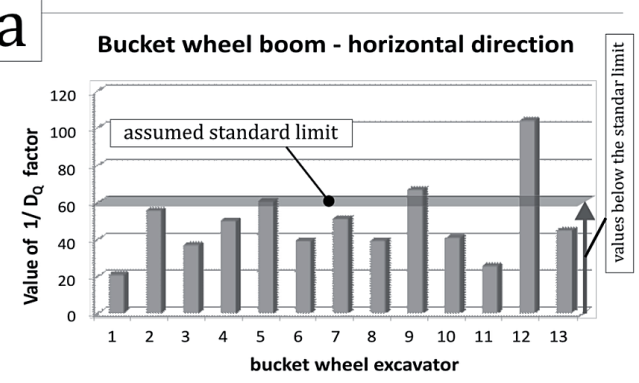

C Counterweight boom - horizontal direction

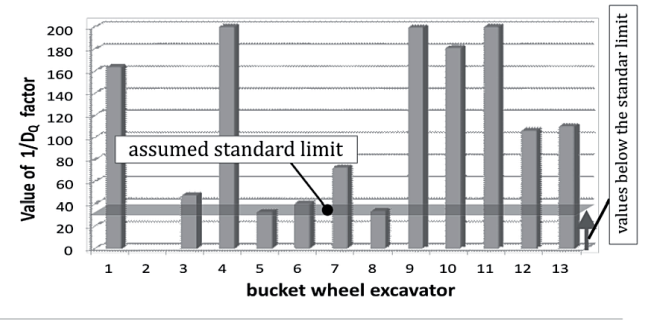

b Bucket wheel boom - vertical direction

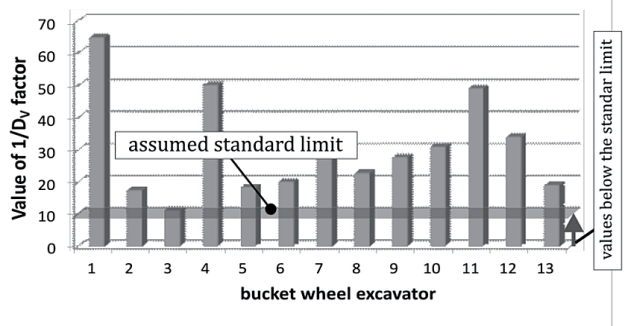

Fig. 6. Comparison of measured values of the dynamic effects factor for bucket wheel excavators

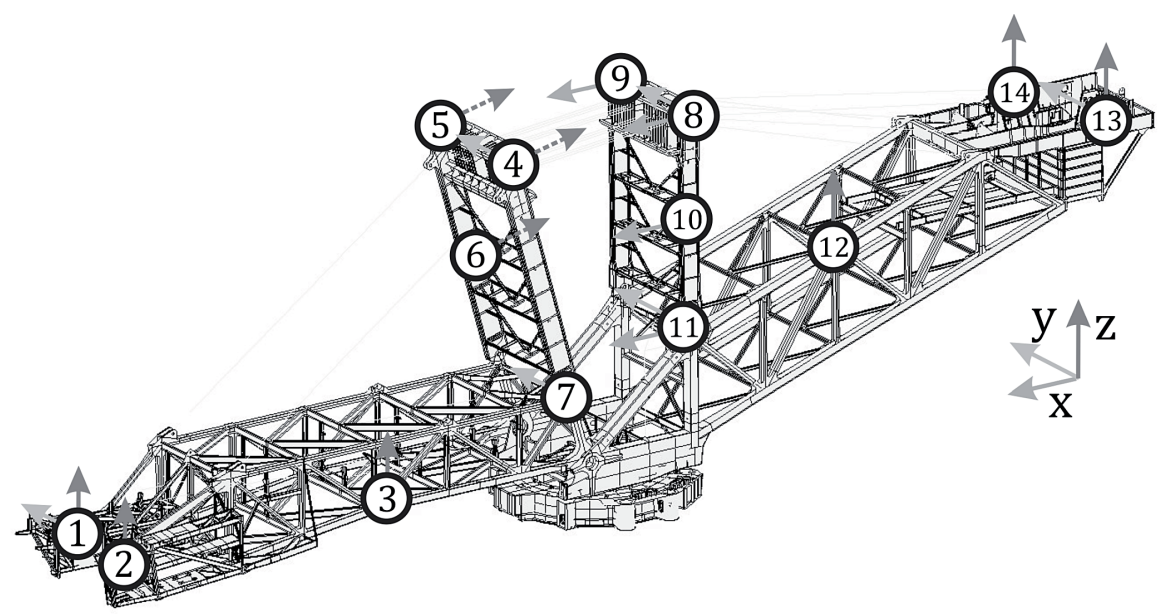

Fig. 4. Grid of measurement points - SchRs 4000.37, 5 excavator

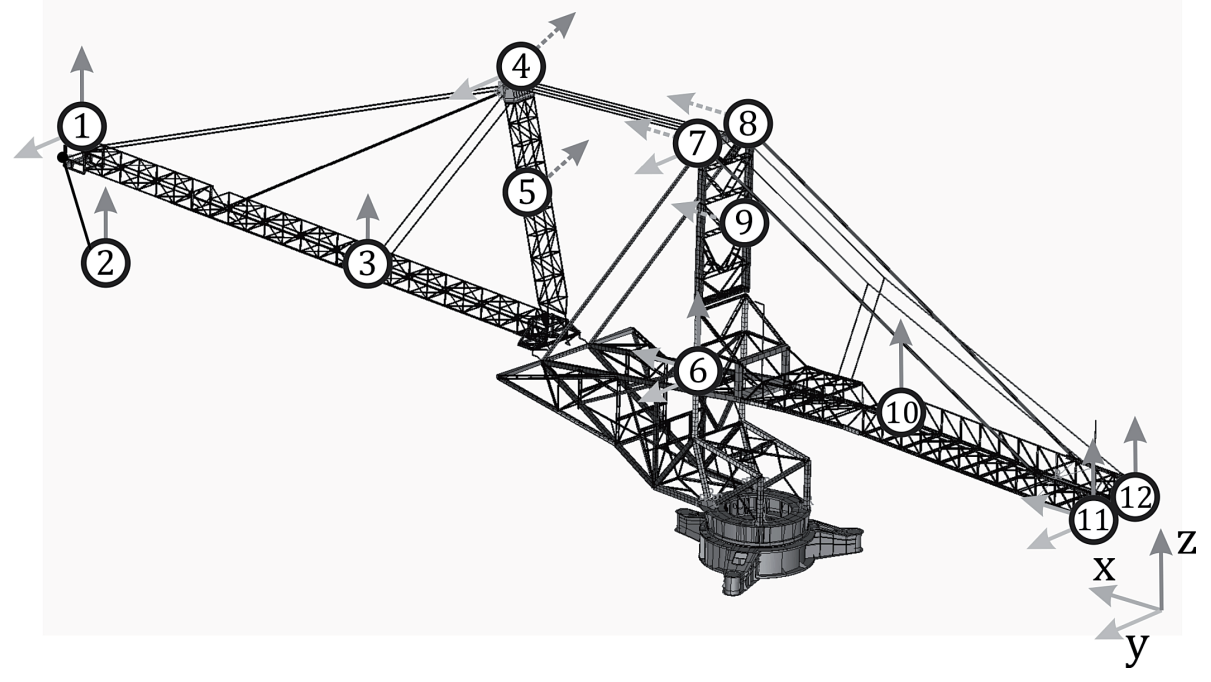

Fig. 5. Grid of measurement points $-A_{2} R s B 12500$ stacker studies have shown that the most frequently exceeded operational parameters are the assumed dynamic loads [6, 42-43]. Measurements were performed on more than 20 machines operating in standard conditions. The grid of measurement points was more than twice as dense as the one proposed by the DIN standard. Their distribution for two sample machines is shown in Fig. 4 and Fig. 5.

Figure 6 and Figure 7 show a comparison of selected measuring points. Fig. 6 is a comparison of experimentally determined levels of dynamic effects for selected representative measuring points which can be compared to the DIN standard. Fig.6a and Fig.6b represent the horizontal and vertical vibrations of the bucket wheel boom respectively, measured at its end (near the attachment of the bucket wheel). Fig.6c and Fig.6d show vibrations of the counterweight boom measured at its end (near the counterweight ballast). It is clearly visible that the highest number of exceedances were observed in the case of horizontal vibrations of the bucket wheel boom and vertical vibrations of the counterweight boom. What is important is that the vertical vibrations of the counterweight boom actually exceed the limit values only in a few cases. This discrepancy between the vertical vibrations of the booms confirms the influence of the excavated material on dynamic characteristics. This phenomenon was described in detail in [28]. Differenczes in the dynamic loads on counterweight booms in the horizontal direction are mainly due to the class of the machines and, consequently, to their design (compact excavators, $\mathrm{C}$-frame machines, large two-mast machines)[38].

In the case of dynamic loads in stackers [9] (Fig. 7) there are exceedances in almost all pre- 


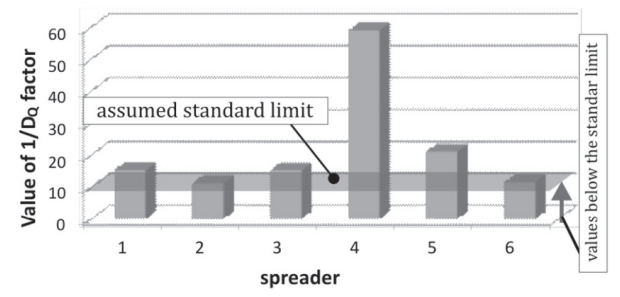

C Counterweight boom - horizontal direction

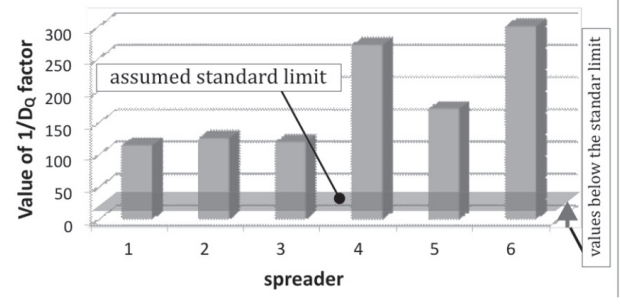

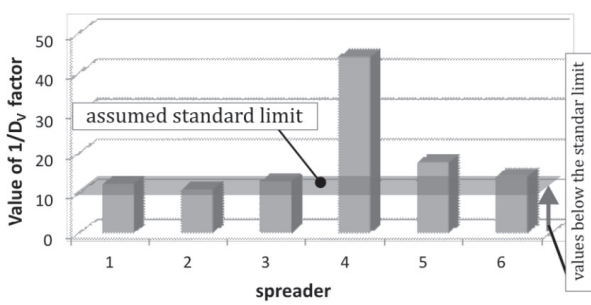

b Discharge boom - vertical direction

d

Counterweight boom - vertical direction

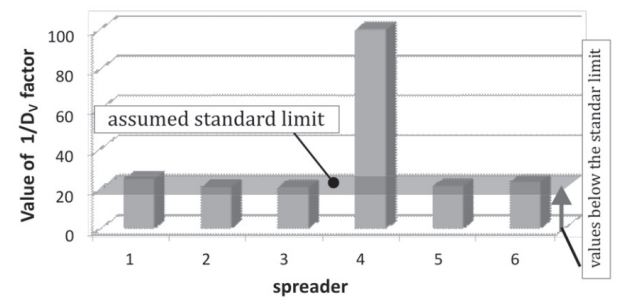

and the main mode of vibrations the superstructure.

Extended studies, still unpublished, have also been carried out on a medium machine (SRs 2000) and a large machine (SchRs $4000.37,5)$. The applied measuring grid is similar to the one shown in Fig. 4, but complemented by strain gauge measuring points on undercarriage track frame. The results confirm the correlation identified during tests on the ŁZKS 1600 machine. The reason why this is more important is that fatigue calculations for undercarriages have not been recommended before. The identified correlation indicates a new direction for studies on the phenomenon of fatigue of largescale machines.

Since literature offers little information on verification of dynamic factors by experimental tests [18], the scale of the research project made it necessary, to develop a method of measurement that is

sented cases and directions. Clearly there are dynamic surpluses in the vertical direction on the discharge boom whose vibrations are not dampened [3] as in the case of excavators, because the boom does not come in contact with the slope of the stockpile. The most relevant values of dynamic surpluses, in comparison to standard values, are those measured on the counterweight boom in the horizontal direction (Fig. 7d).

Additionally, preliminary studies have been carried out on the ŁZKS 1600 stacker-reclaimer, which were designed to verify the actual influence of dynamic loads on the undercarriages of machines. Unlike the method used in the DIN standard, accelerometers were not placed on the elements of the undercarriage, but instead strain gauges were attached to selected elements of the undercarriage. The studies investigated the correlation between the load measured by the strain gauges and the acceleration measured on the bucket wheel boom (Fig. 8). These studies are described in detail in [31]. They show a clear dependency between the loading cycles in the undercarriage,

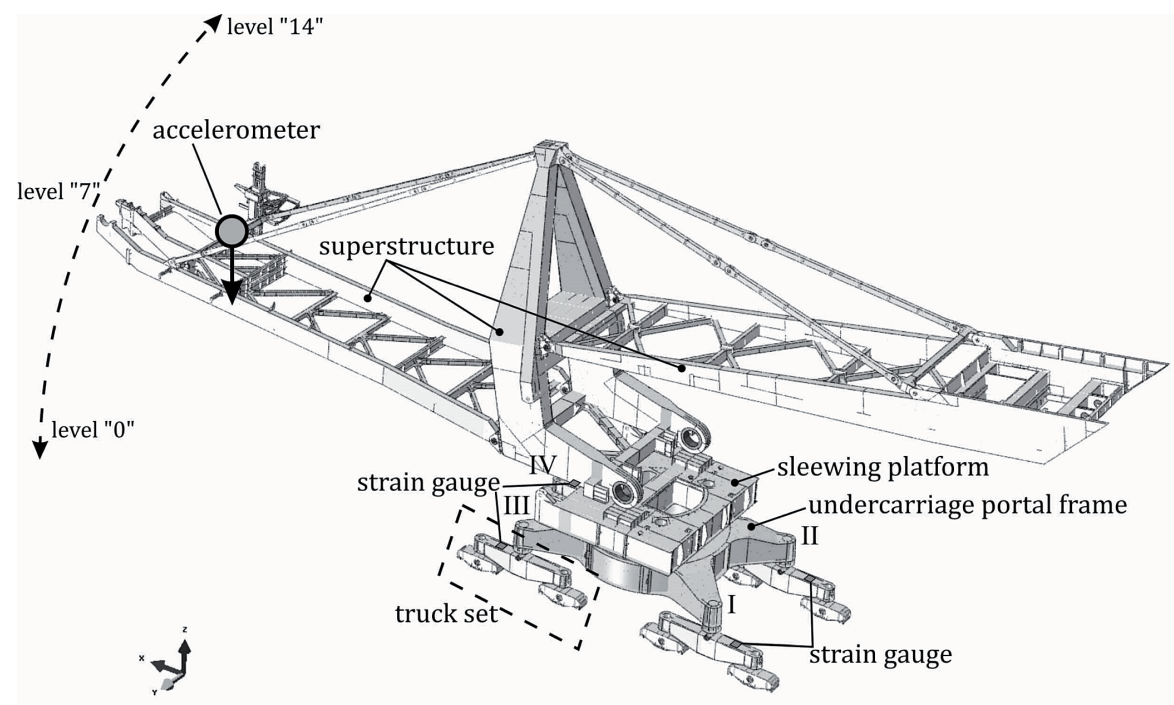

Fig. 8. Studies on the correlation between the dynamics of the superstructure and undercarriage loads [31] identical for each type of machine under study.

In total more than 20 excavators and stackers were tested for superstructure dynamics and for the correlation between undercarriage loads and superstructure dynamics. The results were used to develop and standardize the method of experimental verification of actual values of dynamic load factors. This method establishes the criteria for the selection of measuring points, measurement parameters and signal analysis. The most important guidelines for this method are as follows:

- the measurement points cannot coincide with nodes of natural frequency mode shapes

- when determining the factor that takes into account the loads to elements of undercarriages, the measuring points should be defined in the center of mass of the superstructure elements

- when determining the factor in order to apply load to the undercarriage, the bandwidth range should be limited only to the first mode shape

- in order to analyse the changes in characteristics, the required spectral resolution should be $1 / 100$ of the lowest expected frequency (the first mode shape of the superstructure)

- the goal of data acquisition and signal analysis should be zero loss of signal energy.

In addition, in the studies of the dynamic effects factor, the peak-to-peak value was replaced by the RMS value over the entire measurement. Such a definition of the factor makes it insensitive to individual impact overload [23,25]. In contrast to the recommendations in the standard, the tests should also include the dynamic effects factor in the longitudinal direction. This is particularly important in elements that are directly connected with the superstructure platform because, in these cases, even small values of dynamic effects can lead to strain that is relevant in terms of material fatigue. In the case of elements of the load-carrying structure that support other elements (the central section), it 
is necessary to define the dynamic effects factor associated with each of the loading elements respectively. It also follows that the measurement point designated on one element can be used to evaluate a different area (central section, undercarriage).

\subsection{Development of a designing method that takes into account the dynamic characteristics and the dynamic effects factor}

A major concern from the point of view of design is the use of appropriate values for the dynamic effects factor. As shown in the previous section, these values are almost always exceeded during operation. The second important aspect is the fact that the dynamic effects factor in dynamic calculations is basically used to perform quasi-static calculations, which completely ignore the phenomena related to the dynamics of machines. What follows is that the possibility of resonances occurring due to the operation of the excavating unit is not verified, nor are mode shapes identified, which are a significant part of the dynamic response in the non-resonant area.

Thus, the analysis of the aforementioned facts shows considerable inconsistencies in the commonly used method of design. However, in order to solve the presented technical problems, while applying the dynamic effects factor for dynamic calculations, it was necessary to develop a designing approach that meets these objectives. This problem is rather difficult because in order to verify the adopted approach it is necessary to verify its results through experimental tests. In view of the fact that machines such as bucket wheel excavators or stackers are designed to operate for dozens of years they are not built very frequently and the design and construction process takes several years to complete.

It was possible, however, to carry out such a procedure when a new KWK 1500.1 excavator was being built. In the design stage an innovative approach was used which incorporated both the calculations with the application of the dynamic effects factor (mainly to validate fatigue strength) as well as dynamic calculations using modal analysis. The second element of this approach is crucial. As shown in the previous section the standard values of the dynamic effects factor are often exceeded. As a result, the calculations based on these values do not produce correct results in quantitative terms, which is confirmed by the large number of fatigue cracks that appear after many years of operation. The design approach adopted when designing the KWK 1500.1 excavator is based on the use of standard factors, however, what is most important is the optimization of the load-carrying structure in terms of dynamics so as to ensure the most even and lowest possible distribution of the dynamic response of the structure. Therefore, the steel load-carrying structure is optimized with regard to dynamic characteristics, which has not been done before. In the design stage it was assumed that since, thus far, machines have not been optimized in this respect, by carrying out such a process it will be possible to maintain the values of dynamic factors at the intended standard lev- el. A detailed analysis of the modal characteristics of the system was performed and compared with the assumed operational excitation. On this basis, significant changes have been introduced to the kinematics of the counterweight support system. A detailed description of the conducted research and redesign is in the works [34, 39]. What is most important, however, is that the optimization of the load-carrying structure with regard to dynamics takes place already during the preliminary design stage. This introduces completely new possibilities in terms of potential modifications of the structure. Due to its application in fatigue calculations, the dynamic effects factor was applicable only when the final design was completed and followed by the numerical model with all detailed structural nodeconnections, because it is in those connections where potential regions sensitive to overload were located. Unfortunately, given the fact that at this stage the range of possible changes was very limited, the negative effects were merely mitigated instead of solving the underlying cause. It is quite different when optimization of the load-carrying structure is carried out at the preliminary design stage. It is then possible to introduce significant changes such as a change in the support system of individual machine components (Fig. 9).

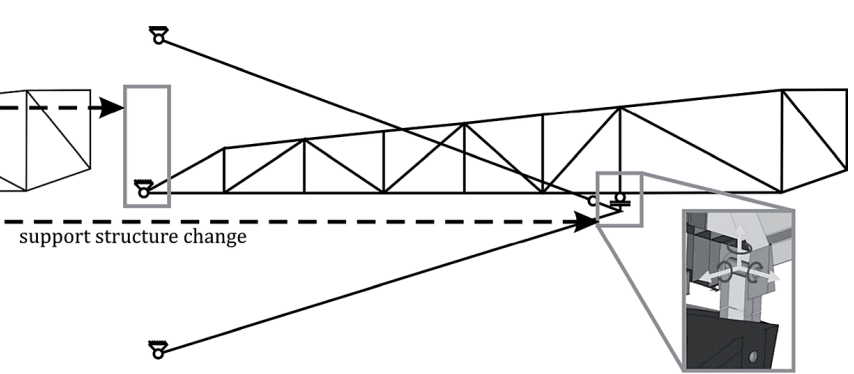

Fig. 9. Conceptual changes during the construction of KWK 1500.1 excavator

The developed design approach is shown in Fig. 10. Its most important advantage is that it is based entirely on the generally accepted design guidelines. The finite element method is used for calculations. It can also be easily implemented for general use. An important difference is in the optimization of the dynamic characteristics of the loadcarrying structure. The developed method consists of three stages, each of which involves an analysis of dynamic characteristics. The method used thus far was limited only to the 2nd stage, excluded modal analysis and dynamic response analysis and included only static calculations with the application of the dynamic effects factor.

The above method makes it possible to significantly reduce the dynamic response of the system in actual operating conditions. The recommendations for verification by experimental tests made it pos-

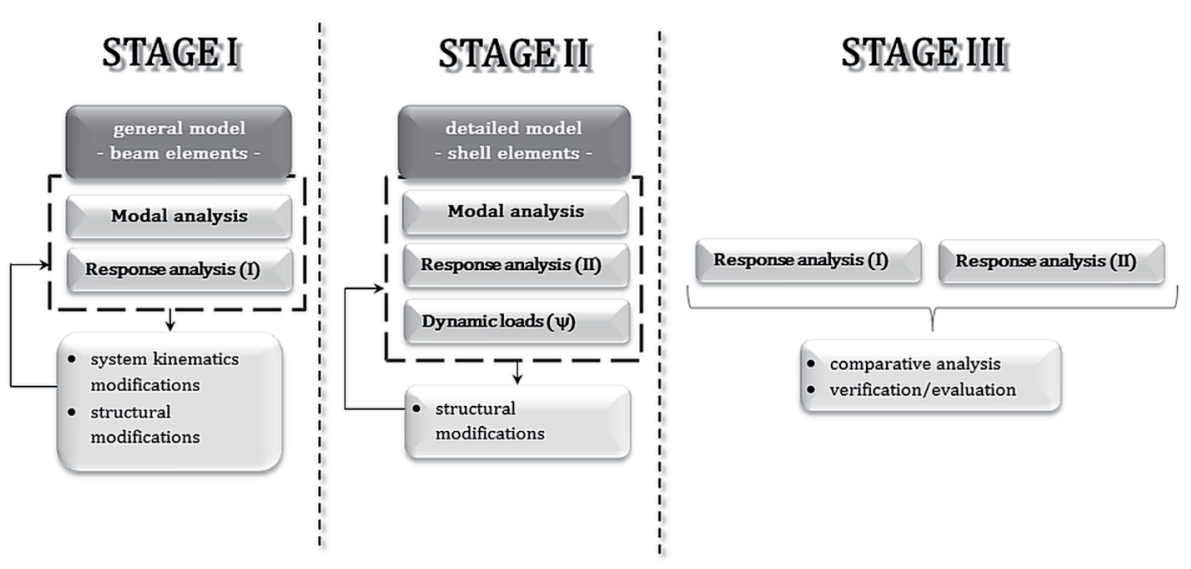

Fig. 10. Design thattakes into account dynamics and the dynamic effects factor 
sible to verify the correctness of the proposed calculation model. Experimental studies $[34,39]$ on the new KWK 1500.1 excavator prototype were compared with studies on excavators of the same class and similar structure: KWK 1500 and KWK 1200 (Fig. 11).

Excavators KWK 1500 and KWK 1500.1 are similar structures, with the difference in that the load-carrying structure of excavator KWK 1500.1 was optimized using the method shown in Figure 10.

What is to be expected is a similar behavior in terms of dynamics. An analysis of the results of experimental tests (table 2) showed tablished in the standard. The proposed model is the only one in the literature, with the calculation method and verification tests.

\section{Method of evaluating large-scale load-carrying struc- tures of machines with the application of the dynamic effects factor}

The purpose of the studies and analyses presented in the second chapter was to directly address the issues of dynamics of surface min-
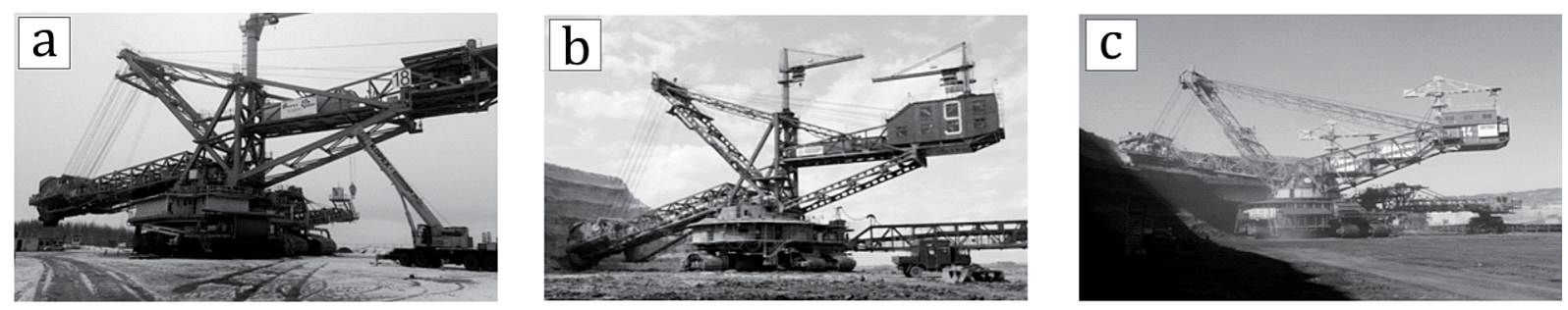

ing machines in the design process. The following three basic problems were identified:

- lack of a calculation method that would be reflected both in the dynamic be-

Table 2. Comparison of dynamic factors [34]

\begin{tabular}{|c|c|c|c|c|c|c|c|c|}
\hline \multirow{2}{*}{$\begin{array}{l}\text { machine } \\
\text { element }\end{array}$} & \multirow{2}{*}{$\begin{array}{l}\text { type of D } \\
\text { factor }\end{array}$} & \multicolumn{3}{|c|}{ Experimental value 1/D } & \multirow{2}{*}{$\begin{array}{c}\text { Standard } \\
\text { value } 1 / D_{N}\end{array}$} & \multicolumn{3}{|c|}{$\mathrm{D}_{\mathrm{N}} / \mathrm{D}$} \\
\hline & & $\begin{array}{l}\text { KWK } \\
1200\end{array}$ & $\begin{array}{c}\text { KWK } \\
1500 \mathrm{~S}\end{array}$ & $\begin{array}{c}\text { KWK } \\
1500.1\end{array}$ & & $\begin{array}{l}\text { KWK } \\
1200\end{array}$ & $\begin{array}{l}\text { KWK } \\
1500\end{array}$ & $\begin{array}{c}\text { KWK } \\
1500.1\end{array}$ \\
\hline \multirow{2}{*}{$\begin{array}{l}\text { bucket wheel } \\
\text { boom }\end{array}$} & average $D_{Q}$ & 45 & 97 & 93 & 60 & 0,75 & 1,62 & 1,54 \\
\hline & average $D_{V}$ & 22 & 41 & 20 & 10 & 2,20 & 4,10 & 2,00 \\
\hline \multirow{2}{*}{$\begin{array}{l}\text { bucket wheel } \\
\text { jib }\end{array}$} & average $D_{Q}$ & 37 & 45 & 208 & 60 & 0,62 & 0,75 & 3,46 \\
\hline & average $D_{V}$ & 35 & 53 & 32 & 10 & 3,48 & 5,30 & 3,18 \\
\hline \multirow{2}{*}{$\begin{array}{l}\text { counterweight } \\
\text { boom }\end{array}$} & average $D_{Q}$ & 132 & 88 & 168 & 30 & 4,40 & 2,95 & 5,61 \\
\hline & average $D_{V}$ & 71 & 84 & 30 & 25 & 2,84 & 3,37 & 1,22 \\
\hline
\end{tabular}

havior and the dynamic effects factor

- lack of information on the incorporation of variable loads in undercarriages of machines

- lack of an experimental method of verifying the actual value of the dynamic effects factor.

The studies presented in the second chapter solve the problems defined above.

The proposed calculation method was complemented by the possibility to apply the dynamic effects factor in calculations of undercarriages. The model has been validated experimentally. Validation was performed using the experimental method of verification tests developed on the basis of research carried out on over 20 machines.

The presented long-term research and a significant difference in the behavior of the jib, which exhibited approximately five times lower vibrations in comparison to the KWK1500 excavator. This difference results from the optimization of dynamic characteristics that was carried out on the KWK 1500.1 excavator. The modification of the support system of the counterweight boom (Fig. 9) significantly altered the kinematics of the entire system. The counterweight boom is connected to the $\mathrm{jib}$ and the bucket wheel boom. It is clear that in the case of the KWK1500.1 machine the measured values of dynamic loads acting on these elements are compliant with the assumed values, which is a direct consequence of the stabilization of the operation of the counterweight boom.

The obtained data can be used to compare the standard values of the factor with the values calculated on the basis of measured acceleration values. The results of such comparison are shown in table $2 . \mathrm{D}_{\mathrm{Q}}, \mathrm{D}_{\mathrm{V}}$ represent the values of the $\psi$ factor in the lateral and vertical directions respectively, whereas $D_{N}$ is their corresponding standard value. The recommended standard values used in calculations are exceeded when the measured $\mathrm{D}$ factor is smaller than the standard $\mathrm{D}_{\mathrm{N}}$ factor. For comparison, the table also shows the values of factors for structurally similar KWK1200 and KWK1500 excavators.

Therefore the developed numerical model and the presented calculation method shows that it is possible to optimize the loadcarrying structure in such a way as to meet the requirements es-

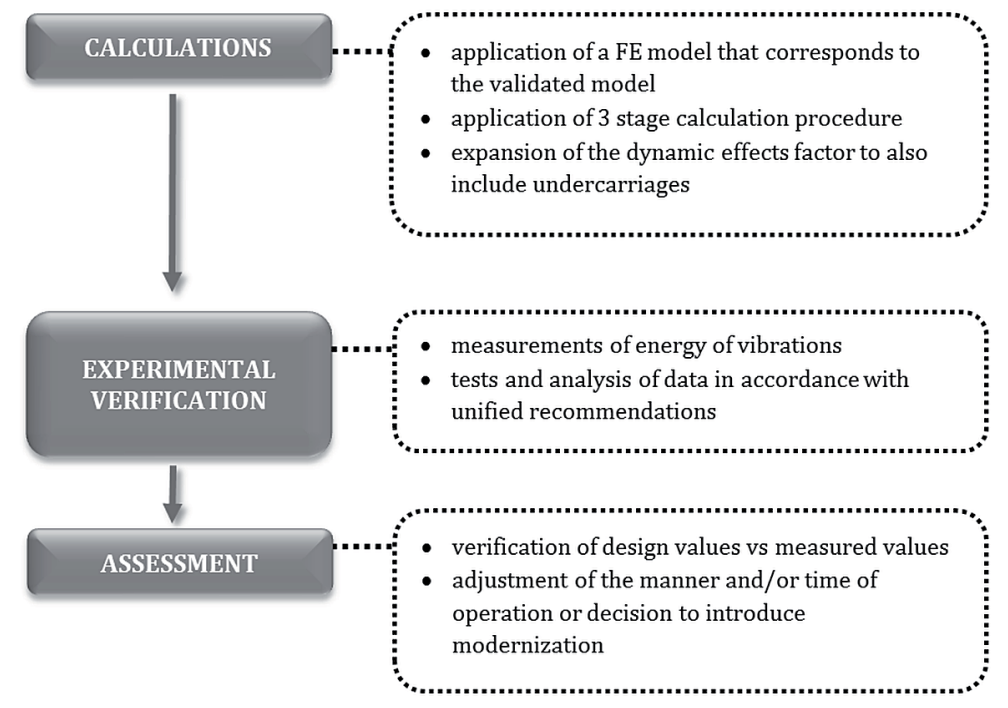

Fig. 12. Method of evaluating large-scale load-carrying structures with the application of the dynamic effects factor 
The method consists of 3 basic steps. The first involves calculations based on the 3-stage calculation method presented in the second chapter, which uses the validated model. In addition, this method extends the calculations to also include the loads acting on undercarriages resulting from dynamic effects that have been observed during the studies. The next step of the evaluation method involves validation by experimental studies that are carried out after the structure is built. In this regard the second chapter presents a unified method of validation by experimental studies that offer the possibility to compare the established standard values with the actual ones. Once this information is available, the third step of the evaluation method commences, in which the validity of identified parameters is evaluated. On this basis a decision can be made to the change the manner and/ or time of operation or to modernize the completed structure. Such a situation can occur if the verification tests demonstrate that the actual values are still higher than the assumed values. Once the actual values of dynamic loads are known it is possible to correct the estimated operational life. Depending on the obtained results new measures can be taken to limit, to a certain degree, the working loads of the machine and thereby decrease the dynamic loads acting on the load-carrying structure. This solution guarantees that the operational life will remain on the initially assumed level. Modifications can also be introduced to the final load-carrying structure if they are justified and feasible. The fact that actual values of the dynamic effects factor exceed the assumed values may also be a consequence of certain assumptions which were made in the designing stage but which cannot be avoided in the case of systems characterized by this level of complexity. It is also necessary to monitor the loads which are the main cause of excitation of the load-carrying structure and to ensure that their assumed values are not exceeded during operation. Such a situation can be the result of faulty operation, poor technical condition of the machine or operation in conditions (e.g. geological) that are different than those in the design. It is also recommended to continue monitoring the actual values of the dynamic effects factor in later stages of operation. By doing this it will be possible to introduced changes that might be necessary to obtain the required life. The successive steps of the evaluation method with the characteristic elements of each step are shown in figure 12.

\section{Conclusions}

The proposed evaluation method fills the gap between the scientific calculation methods that are currently being developed in relation to dynamics of large-scale machines and the commonly known and used methods. Because it is based on the dynamic effects factor for dynamic calculations, which, in accordance with standard recommendations is the basis for these calculations, the proposed method is compatible with all current requirements for designers of large-scale machines.

The primary difference, which offers the greatest benefits from the application of this method, is that the result produced by calculations using this method is not only qualitative but also quantitative. Underestimated dynamic loads still lead to the accelerated degradation of load-carrying structures. The presented method makes it possible to apply changes in design in order to customize the load-carrying structure in such a manner that the dynamic response, measured during operation, corresponds to the values assumed in calculations. Dynamic analysis of the structure at the preliminary design stage offers the possibility to develop completely new structures with optimized dynamic characteristics. In addition, if dynamic characteristics are maintained at the appropriate level, operation becomes easier and not only precise technical and operational parameters related to extraction can be obtained but the precision of estimation of durability can be improved.

Also no indication has been made thus far of a direct correlation between variable loads acting on elements of undercarriages and superstructure vibrations. The presented studies clearly show that such a correlation exists and, in addition, indicate the possibility to approach this phenomenon with the dynamic effects factor, which is also an important element of the method. The demonstrated correlation also offers the possibility to develop other alternative methods for estimating fatigue life of undercarriages of large-scale machines.

To verify the actual values of dynamic loads, a unified method for conducting experimental research has been developed. It is also an integral part of the method of evaluating large-scale load-carrying structures.

The proposed method of evaluating large-scale load-carrying structures with the application of the dynamic effects factor as well as the studies on the basis of which it has been developed, are of high value in the field of technical sciences and applied research. Because the method is based on the commonly used dynamic effects factor it has a great potential for quick application in practice. This is confirmed by theKWK 1500.1 excavator, which was designed and built using the described method.

\section{References}

1. Babiarz S, Dudek D. Failures and catastrophes in Polishsurfacemining - In Polish. Wroclaw University of Technology Publishing House 2007.

2. Bialas K. Electrical Elements in Reduction of Mechanical Vibrations. Applied Mechanics and Materials, 2013; 371: 657-66.

3. Bocian M, Jamroziak K, Kulisiewicz M. The identification of nonlinear damping of the selected components of MDOF complex vibratory systems. [in:] A. Cunha, E. Caetano, P. Ribeiro, G. Müller (eds.), Proceedings of the 9th International Conference on Structural Dynamics, EURODYN 2014, Porto, Portugal, 30 June - 2 July 2014; 3365-3372.

4. Bosnajk S, Petkovic Z, Simonovic A, Zrnic N, Gnjatovic N. Designing-in failures and redesign of bucket wheel excavator undercarriage. Engineering Failure Analysis 2013; 35: 95-103, https://doi.org/10.1016/j.engfailanal.2012.12.007.

5. BosnjakS M, Oguamanam D C D, Zrnic N D. The influence of constructiveparameters on responsepfbucketwheelexcavatorsuperstructure. Archives of Civil and Mechanical Engineering 2015; 15: 977-985.

6. Brkić A Đ, Maneski T, Ignjatović D, Jovančić P, SpasojevićBrkić V K. Diagnostics of bucket wheel excavator discharge boom dynamic performance and its reconstruction. Eksploatacja i Niezawodnosc - Maintenance and Reliability 2014; 16 (2): $188-197$.

7. Cristea D. In Situ Modal Testing Methods For Huge Structures Applications to Surface Mining Machines Annals of the University of Petroşani, Mechanical Engineering 2007; 9: 97-102.

8. Czmochowski J, Kowalczyk M, Pietrusiak D, Przybyłek G, Rusiński E. Metodyka oceny stanu technicznego maszyn górniczych w kopalniach odkrywkowych. Problemy rozwoju maszyn roboczych / red. Andrzej Kosucki. Łódź : Wydawnictwo Politechniki Łódzkiej; 2015: 65-76.

9. Czmochowski J, Moczko P, Pietrusiak D, Przybyłek G, Rusiński E. Selected Aspects of Technical Condition State Assessment of Spreaders Operating in Lignite Mines. Proceedings of the 13th International Scientific Conference Computer Aided Engineering, Polanica Zdrój, 
Poland, June 22-25, 2016: 89-98.

10. Czmochowski J, Moczko P, Pietrusiak D, Rusiński E. Numeryczno-Eksperymentalna Analiza Drgań Zwałowarki w Stanach Nieustalonych. Materiały Konferencyjne - XXX Konferencja Problemy Rozwoju Maszyn Roboczych, 24-27.01.2017, Zakopane; 2017.

11. Czmochowski J. Identification of modal models of brow coal excavation machines - In Polish. Wroclaw University of Technology Publishing House; 2008.

12. Danicic D, Sedmak S, Ignjatovic D, Mitrovic S. Bucket wheel excavator damage by fatigue fracture - case study. Procedia Materials Science 2014;3: 1723 - 1728. https://doi.org/10.1016/j.mspro.2014.06.278

13. Derlukiewicz D, Kowalczyk M, Moczko P, Smolnicki T. Selected Aspects Of Loads Identification In Caterpillar Undercarriage Of Bucket Wheel Excavator, 25th Danubia-Adria Symposium On Advances In Experimental Mechanics 2008: 55-56.

14 Equipment in Brown Coal Open $\mathrm{Cu}$ tMines Part 2 Calculation Principals Technischen Normen, Gütevorschriftenund Lieferbedingungen, TGL 13472 Stahlbau Stahltragwerke der Hebezeuge; Berechnung, bauliche Durchbildung1974.

15. Fiebig W, Wróbel J. Two stage vibration isolation of vibratory shake-out conveyor. Archives of Civil and Mechanical Engineering 2017; 17 : 199-204, https://doi.org/10.1016/j.acme.2016.10.001.

16. Filizikowski J, Macko M. Method of estimation of efficiency of quasi-cutting of recycled opto-telecommunication pipes. Polimery 2001; 46(1): 53-59.

17. Flizikowski J, Macko M. Competitive design of shredder for plastic in recycling, Tools And Methods Of Competitive Engineering 2004; 1/2: 1147-1148.

18. German Institute for Standardization, DIN 22261-2 Excavators, Stackers and Auxillary Equipment in Brown Coal Open Cut Mines Part 2 Calculation Principals 2015.

19. Gnjatovic N. Influence of constructional parameters and parameters of excitation on response of the bucket wheel excavator with two masts in the out-of-resonance region. PhD Thesis, University of Belgrade, 2016.

20. Huss W. Metoda identyfikacji stanów nieustalonych ustroju nośnego koparki kołowej przy obciążeniach losowych. Politechnika Wrocławska, Rozprawa Doktorska, 2012.

21. Idehara S J, Junio . D. Modal analysis of structures under non-stationary excitation. Engineering Structures 2015; 99: 56-62, https://doi. org/10.1016/j.engstruct.2015.04.035.

22. International Organization for Standardization, ISO5049.1: Mobile Equipment for the Continuous Handling of Bulk Materials Part 1 Rules for the Design of Steel Structures, 1994.

23. Jabłoński M, Ozga A. Determining the distribution of values of stochastic impulses acting on a discrete system in relation to their intensity. Acta Physica Polonica A; 2012: 121(1): 174-178, https://doi.org/10.12693/APhysPolA.121.A-174.

24. Kowalczyk M. Wymiarowanie spawanych konstrukcji nośnych maszyn podstawowych górnictwa odkrywkowego w zakresie trwałości zmęczeniowej, Rozprawa Doktorska, Politechnika Wrocławska, 2010.

25. Pach J, Pyka D, Jamroziak K, Mayer P. The experimental and numerical analysis of the ballistic resistance of polymer composites. Composites Part B: Engineering; 2017; 113: 24-30, https://doi.org/10.1016/j.compositesb.2017.01.006.

26. Piątkiewicz A, Sobolski R. Dźwignice, tom 1, WNT 1978.

27. Piątkiewicz A, Sobolski R. Dźwignice, tom 2, WNT 1978.

28. Pietrusiak D. Assessment of the bucket wheel excavators load carrying structures dynamics with use of the modal analysis (Doctoral dissertation - In Polish), Wroclaw University of Technology Institute of Machine Design and Operation, 2013.

29. Pietrusiak D, Moczko P, Rusiński E. Recent achievements in investigations of dynamics of surface mining heavy machines. 24th World Mining Congress : mining in a world of innovation - proceedings, October 18-21, 2016, Rio de Janeiro, Brazil. Rio de Janeiro : IBRAM, 2016: $295-308$.

30. Pietrusiak D, Moczko P, Rusiński R. World's largest movable mining machine vibration testing - numerical and experimental approach. Proceedings of ISMA2016 International Conference on Noise and Vibration Engineering, USD2016 International Conference on Uncertainty in Structural Dynamics 19 to 21 September, 2016 / eds. P. Sas, D. Moens, A. van de Walle. Leuven : Katholieke Universitet Leuven, 2016: 2287-2299.

31. Pietrusiak D, Smolnicki S, Stańco M. The influence of superstructure vibrations on operational loads in the undercarriage of bulk material handling machine. Archives of Civil and Mechanical Engineering, https://doi.org/10.1016/j.acme.2017.03.001.

32. Płaczek M, Buchacz A, Wróbel A. Use of piezoelectric foils as tools for structural health monitoring of freight cars during exploitation. Eksploatacja i Niezawodnosc - Maintenance and Reliability 2015; 17 (3): 443-449, http://dx.doi.org/10.17531/ein.2015.3.16.

33. Rusinski E, Dragan S, Moczko P, Pietrusiak, D. Implementation of experimental method of determining modal characteristics of surface mining machinery in the modernization of the excavating unit. Archives of Civil and Mechanical Engineering, 2012; 12(4):, 471-476, https://doi.org/10.1016/j.acme.2012.07.002.

34. Rusinski E, Moczko P, Pietrusiak D. Low frequency vibrations of the surface mining machines caused by operational loads and its impact on durability. Proceedings of International Conference on Noise and Vibration Engineering (ISMA2014) and International Conference on Uncertainty in Structural Dynamics (USD2014), 2014: 683-694.

35. Rusiński E, et al. Ocena Stanu Technicznego Maszyn Podstawowych Górnictwa Odkrywkowego. Oficyna Wydawnicza Politechniki Wrocławskiej, 2015.

36. Rusiński E, Czmochowski J, Moczko P, Pietrusiak D. Challenges and strategies of long-life operation and maintenance of technical objects, FME Transactions 2016; 44: 219-228.

37. Rusiński E, Czmochowski J, Iluk A, Kowalczyk M. An analysis of the causes of a BWE counterweight boom support fracture. Engineering Failure Analysis 2010; 1(17): 179-191, https://doi.org/10.1016/j.engfailanal.2009.06.001.

38. Rusiński E., Czmochowski J., Moczko P., Pietrusiak D.SurfaceMiningMachines - Problems of Maintenance and Modernization, Springer Nature, 2017

39. Rusiński E, Moczko P, Pietrusiak D. Analiza dynamiki wielonaczyniowych koparek kołowych typu KWK, Górnictwo Odkrywkowe 2014; 55(4/5): 197-202.

40. Rusiński E, et. al. Analiza techniczno-ekonomiczna możliwości zastosowania w odkrywce Złoczew maszyn podstawowych pracujących w 
KWB Bełchatów. Raporty Wydziału Mechanicznego Politechniki Wrocławskiej. 2016,, Ser. SPR ; nr 133, 2015.

41. Rusiński E, et al. Badania, ekspertyza i diagnostyka maszyn podstawowych KWK-1200M (K-27), ARsP-6500 (Z-45). Raporty Inst. Konstr. Ekspl. Masz. PWroc. 2010, Ser. SPR; nr 87, 88, Politechnika Wrocławska, 2010.

42. Rusiński E, et. al. Badania, ekspertyzy i diagnostyka maszyn podstawowych KWK-1500s (K-9), KWK-1200M (K-14), SchRs-1200 9K-22). Raporty Inst. Konstr. Ekspl. Masz. PWroc. 2009,, Ser. SPR ; nr 90, 91, 92, Politechnika Wrocławska, 2009.

43. Rusiński E, et. al. Badanie ustrojów nośnych maszyn podstawowych. Raporty Wydziału Mechanicznego Politechniki Wrocławskiej 2015, Ser. SPR ; nr 164, 2015.

44. Rusiński E, et al. Ocena stanu technicznego zużycia maszyn podstawowych pracujących w KWB Konin. Etap 1, Ocena stanu technicznego i wykonanie badań na koparkach SchRs-800 i SchRs-1200 pod kątem określenia dalszej możliwości ich pracy Raporty Inst. Konstr. Ekspl. Masz. PWroc. 2010, Ser. SPR; nr 56, Politechnika Wrocławska, 2010.

45. Rusiński E, et al. Ocena stanu technicznego zużycia maszyn podstawowych pracujących w KWB Konin. Etap II, Ocena stanu technicznego i wykonanie badań na koparkach SRs 1200/5 i SRs 1200/6 pod kątem określenia możliwości pracy jednej z nich na O/Ościsłowo. Raporty Inst. Konstr. Ekspl. Masz. PWroc. 2011, Ser. SPR; nr 39, Politechnika Wrocławska, 2010.

46. Rusiński E, Dudek K, Moczko P. Degradation of undercarriage portal frames of surface mining machines - In Polish. Transport Przemysłowy 2006; 2(24): 40-43.

47. Standards Australia AS4324.1: Mobile equipment for continuous handling of bulk materials Part 1 - General requirements for the design of steel structures, 1995.

48. Weber F, Feltrin G, Maślanka M, Fobo W, Distl H. Design of viscous dampers targeting multiple cable modes. Engineering Structures 2009; 31: 2797-2800, https://doi.org/10.1016/j.engstruct.2009.06.020.

\section{Damian PIETRUSIAK}

Department of Machine Design and Research

Faculty of Mechanical Engineering

Wrocław University Of Science Technology

ul. Łukasiewicza 7/9, 50-371 Wrocław, Poland

E-mail: damian.pietrusiak@pwr.edu.pl 